\title{
Sulfonamide inhibition profile of the $\gamma$-carbonic anhydrase identified in the genome of the pathogenic bacterium Burkholderia pseudomallei the etiological agent responsible of melioidosis
}

\author{
Sonia Del Prete ${ }^{\mathrm{a}}$, Daniela Vullo ${ }^{\mathrm{b}}$, Pietro Di Fonzo ${ }^{\mathrm{a}}$, Sameh M. Osman ${ }^{\mathrm{c}}$, Zeid AlOthman ${ }^{\mathrm{c}}$, William A. Donald ${ }^{\mathrm{d}}$, \\ Claudiu T. Supuran ${ }^{\mathrm{c}, \mathrm{d}, \mathrm{e}, *}$, Clemente Capasso ${ }^{\mathrm{a}, *}$ \\ a Istituto di Bioscienze e Biorisorse, CNR, Via Pietro Castellino 111, Napoli, Italy \\ ${ }^{\mathrm{b}}$ Università degli Studi di Firenze, Dipartimento Di Chimica, Laboratorio di Chimica Bioinorganica, Polo Scientifico, Via della Lastruccia 3, 50019 Sesto Fiorentino, Florence, Italy \\ ${ }^{c}$ Department of Chemistry, College of Science, King Saud University, P.O. Box 2455, Riyadh 11451, Saudi Arabia \\ ${ }^{\mathrm{d}}$ School of Chemistry, University of New South Wales, Sydney, New South Wales 2052, Australia \\ e Università degli Studi di Firenze, Dipartimento Neurofarba, Sezione di ScienzeFarmaceutiche e Nutraceutiche, Via U. Schiff 6, 50019 Sesto Fiorentino, Florence, Italy
}

\section{A R T I C L E I N F O}

\section{Article history:}

Received 27 October 2016

Revised 7 December 2016

Accepted 10 December 2016

Available online 12 December 2016

\section{Keywords:}

Carbonic anhydrase

$\gamma$-Class

Inhibitor

Sulfonamide

Sulfamate

Acetazolamide

Drug resistance

Burkholderia pseudomallei

\begin{abstract}
A B S T R A C T
A new $\gamma$-carbonic anhydrase (CA, EC 4.1.1.1) was cloned and characterized kinetically in the genome of the bacterial pathogen Burkholderia pseudomallei, the etiological agent of melioidosis, an endemic disease of tropical and sub-tropical regions of the world. The catalytic activity of this new enzyme, BpsCA $\gamma$, is significant with a $\mathrm{k}_{\mathrm{cat}}$ of $5.3 \times 10^{5} \mathrm{~s}^{-1}$ and $\mathrm{k}_{\mathrm{cat}} / \mathrm{K}_{\mathrm{m}}$ of $2.5 \times 10^{7} \mathrm{M}^{-1} \times \mathrm{s}^{-1}$ for the physiologic $\mathrm{CO}_{2}$ hydration reaction. The inhibition constant value for this enzyme for 39 sulfonamide inhibitors was obtained. Acetazolamide, benzolamide and metanilamide were the most effective ( $K_{\mathrm{I}} \mathrm{S}$ of 149-653 nM) inhibitors of BpsCA $\gamma$ activity, whereas other sulfonamides/sulfamates such as ethoxzolamide, topiramate, sulpiride, indisulam, sulthiame and saccharin were active in the micromolar range ( $\mathrm{K}_{\mathrm{I}} \mathrm{s}$ of $\left.1.27-9.56 \mu \mathrm{M}\right)$. As Burkholderia pseudomallei is resistant to many classical antibiotics, identifying compounds that interfere with crucial enzymes in the $B$. pseudomallei life cycle may lead to antibiotics with novel mechanisms of action.
\end{abstract}

(c) 2016 Elsevier Ltd. All rights reserved.
In all living organisms, the interconversion of $\mathrm{CO}_{2}$ and $\mathrm{HCO}_{3}^{-}$is balanced naturally to maintain the equilibrium between dissolved inorganic carbon dioxide $\left(\mathrm{CO}_{2}\right)$, carbonic acid $\left(\mathrm{H}_{2} \mathrm{CO}_{3}\right)$, bicarbonate $\left(\mathrm{HCO}_{3}^{-}\right)$and carbonate $\left(\mathrm{CO}_{3}^{2-}\right)$. All these molecules have a pivotal function in all lifeforms. For example, $\mathrm{CO}_{2}$ is fixed as 3-phosphoglycerate (3-PGA) in plants by the photosynthetic $\mathrm{C} 3$ cycle, through the action of RuBisCo, ${ }^{1,2}$ which is the only enzyme capable of net carbon assimilation in the chloroplast stroma; $\mathrm{HCO}_{3}^{-}$is the substrate of phosphoenolpyruvate carboxylase (PEPC), which is the enzyme involved in the formation of oxaloacetate in the mesophyll cells of the $\mathrm{C} 4$ photosynthetic plants ${ }^{3}$; moreover, $\mathrm{HCO}_{3}^{-}$is the main molecule used by other carboxylating enzymes involved in biosyn-

\footnotetext{
* Corresponding authors at: Istituto di Bioscienze e Biorisorse, CNR, Via Pietro Castellino 111, Napoli, Italy (C. Capasso) and Università degli Studi di Firenze, Dipartimento Neurofarba, Sezione di ScienzeFarmaceutiche e Nutraceutiche, Via U. Schiff 6, 50019 Sesto Fiorentino, Florence, Italy (C.T. Supuran).

E-mail addresses: claudiu.supuran@unifi.it (C.T. Supuran), clemente.capasso@ ibbr.cnr.it (C. Capasso).
}

thetic pathways of fatty acids, amino acids and nucleotides in animals. Thus, the $\mathrm{HCO}_{3}^{-} / \mathrm{CO}_{3}^{2-}$ ratio is fundamental to buffering the $\mathrm{pH}$ in many tissues and various organisms. For all organisms and tissues, the spontaneous hydration/dehydration reaction (1) is very slow at physiological $\mathrm{pH}^{4}$

$\mathrm{CO}_{2}+\mathrm{H}_{2} \mathrm{O} \leftrightharpoons \mathrm{HCO}_{3}^{-}+\mathrm{H}^{+}$

To face this problem, all life forms evolved a specific family of metalloenzymes, the carbonic anhydrases (CAs, EC 4.2.1.1), with the primary function to strongly accelerate the interconversion of $\mathrm{CO}_{2}$ and $\mathrm{HCO}_{3}^{-5} .^{-9}$ This superfamily includes seven distinct classes known as the $\alpha-, \beta-, \gamma-, \delta-, \zeta-, \eta$ - and $\theta_{-C A s}{ }^{10-18}$ These enzymes are involved in many physiologic processes, such as photosynthesis, respiration, $\mathrm{CO}_{2}$ transport, as well as metabolism of xenobiotics (e.g., cyanate in Escherichia coli). Some of the catalytically active $\alpha$ - and $\theta_{-C A s}$ can also catalyze the hydrolysis of esters, such as 4-nitrophenyl acetate (4-NpA). However, no esterase activity was detected so far for enzymes belonging to the other five classes $(\beta-, \gamma-, \delta-, \zeta-$, and $\eta-C A s) .{ }^{11-13,16,19-21}$ 
Bacteria encode for enzymes belonging to $\alpha$-, $\beta$ - and $\gamma$-CA classes. $\alpha$ - and $\gamma$-CAs contain zinc ion $\left(\mathrm{Zn}^{2+}\right)$ in their active site, coordinated by three histidine residues and a water molecule/ hydroxide ion, whereas in $\beta$-CAs the zinc ion is coordinated by two Cys and one His residues. In the search for antibiotics with a novel mechanism of action, a large number of CAs have been investigated in detail in pathogenic bacteria such as Helicobacter pylori, Brucella suis, Mycobacterium tuberculosis, Streptococcus pneumoniae, Salmonella enterica, Vibrio cholerae, Legionella pneumophila, Porphyromonas gingivalis, Streptococcus mutans and others. ${ }^{9,16,17,22}$ It has been shown that the use of inhibitors of this family of metalloenzymes leads to growth defects of the pathogen. Thus, it is feasible that new strategies for the development of antiinfectives with a new and less explored mechanism of action can be developed. The classical CA inhibitors (CAIs) are the primary sulfonamides, $\mathrm{RSO}_{2} \mathrm{NH}_{2}$, which have been in clinical use for more than 60 years as diuretics, and systemically acting antiglaucoma drugs. ${ }^{23,24}$ For example, there are several clinically used drugs (or agents in clinical development) belonging to the sulfonamide or sulfamate classes, which show significant CAI inhibitory activity (Fig. 1). ${ }^{1,25-32}$ However, recently sulfonamide/sulfamate CAIs have emerged for targeting the bacterial proteins and have the potential for use as antiinfectives. ${ }^{17,21,25,27,33-40}$ In Fig. 1, a large number of sulfonamides/sulfamates are shown that are often used for the screening of the inhibition profile of various CAs, including bacterial enzymes belonging to all three classes $(\alpha, \beta$ and ү). ${ }^{6,8,9,11,13,14,41-44}$

Among the Gram-negative saprophytic bacteria living in water and soil, Burkholderia pseudomallei is the etiological agent responsible for melioidosis, which is an endemic disease of tropical and sub-tropical regions. ${ }^{45}$ Humans can be infected by skin inoculation, inhalation, and ingestion of contaminated water and soil. Infected people can manifest symptoms, such as bacteremia with septic shock, pneumonia, pericarditis, genitourinary infections, inflammation of parotid glands, central nervous system infection, septic arthritis, abscess involving spleen, liver and adrenal glands. ${ }^{45}$

We investigated the presence of CAs in the genome of $B$. pseudomallei due to the following reasons: $i$ ) Burkholderia pseudomallei is<smiles>Nc1cccc(S(N)(=O)=O)c1</smiles>

1<smiles>NCc1ccc(S(N)(=O)=O)cc1</smiles>

5<smiles>Nc1ccc(S(N)(=O)=O)cc1Br</smiles>

9<smiles>Nc1nnc(S(N)(=O)=O)s1</smiles>

13<smiles>Nc1ccc(S(N)(=O)=O)cc1</smiles><smiles>NCCc1ccc(S(N)(=O)=O)cc1</smiles>

6<smiles>NS(=O)(=O)c1cc(Cl)cc(Cl)c1O</smiles>

10<smiles>NS(=O)(=O)c1cccc(S(N)(=O)=O)c1</smiles>

3<smiles>Nc1ccc(S(N)(=O)=O)cc1F</smiles>

$$
7
$$<smiles>Nc1cc(C(F)(F)F)c(S(N)(=O)=O)cc1S(N)(=O)=O</smiles>

11<smiles>NS(=O)(=O)c1ccc(CO)cc1</smiles>

15: $\mathrm{n}=0$ 16: $\mathrm{n}=1$ $17: n=2$<smiles>Cc1ccc(S(N)(=O)=O)cc1</smiles>

4<smiles>Nc1ccc(S(N)(=O)=O)cc1Cl</smiles>

8<smiles>Nc1cc(Cl)c(S(N)(=O)=O)cc1S(N)(=O)=O</smiles>

12<smiles>NS(=O)(=O)c1ccc(C(=O)O)cc1</smiles>

18

14

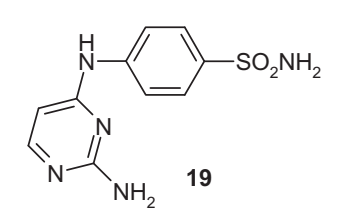<smiles>Nc1ccc(S(=O)(=O)Nc2nnc(S(N)(=O)=O)s2)cc1</smiles><smiles>Nc1ccc(S(=O)(=O)N[Ga]c2ccc(S(N)(=O)=O)cc2)cc1</smiles>

Fig. 1. Sulfonamides/sulfamates that were investigated as CAIs. 
<smiles>CC(=O)Nc1nnc(S(N)(=O)=O)s1</smiles><smiles>CCOC(=O)c1nn(C)c(=[Sb](N)=O)s1</smiles><smiles>CCOc1ccc2nc(S(N)(=O)=O)sc2c1</smiles>

AAZ<smiles>CCN[C@H]1C[C@@H](C)S(=O)(=O)c2sc(S(N)(=O)=O)cc21</smiles>

DZA<smiles>CCN[C@H]1CN(CCOC)S(=O)(=O)c2sc(S(N)(=O)=O)cc21</smiles>

BRZ<smiles>NS(=O)(=O)c1nnc(NS(=O)(=O)c2ccccc2)s1</smiles>

BZA<smiles>CC1(C)O[C@@H]2O[C@@]3(COS(N)(=O)=O)OC(C)(C)O[C@@H]3[C@H]2O1</smiles><smiles></smiles><smiles>COc1ccc(S(N)(=O)=O)cc1C(=O)NCC1CCCN1C</smiles>

SLP<smiles>NS(=O)(=O)c1ccc(S(=O)(=O)Nc2cccc3c(Cl)c[nH]c23)cc1</smiles>

IND<smiles>Cc1onc(-c2ccccc2)c1-c1ccc(S(N)(=O)=O)cc1</smiles>

VLX<smiles>NS(=O)(=O)c1ccc(-n2nc(C(F)(F)F)cc2-c2ccc(C(F)(F)F)cc2)cc1</smiles>

CLX<smiles>NS(=O)(=O)c1ccc(N2CCCCS2(=O)=O)cc1</smiles>

SLT<smiles>NS(=O)(=O)c1cc2c(cc1Cl)NCNS2(=O)=O</smiles>

HCT

Fig. 1 (continued)

fundamentally resistant to penicillin, ampicillin, first-generation and second-generation cephalosporins, macrolides, quinolones and most aminoglycosides; $i i$ ) it has been reported that the optimal proliferation temperature of this bacterium is around $40{ }^{\circ} \mathrm{C}$ in neutral or slightly acidic conditions ( $\mathrm{pH}$ 6.8-7.0), which might be controlled by CAs, which are enzymes that are involved in the $\mathrm{pH}$ homeostasis in all living organisms. ${ }^{46}$

Owing to the limited therapeutic options for treating Burkholderia pseudomallei induced infections and the pivotal role of CAs in $\mathrm{pH}$ homeostasis, targeting the CA family is a promising to discover new antibacterials devoid of resistance problems. B. pseudomallei genome encodes for at least three $\beta$-CAs and one $\gamma$-CA, but not for $\alpha$-class enzymes. Here, we report the inhibition profiles of BpsCA $\gamma$ in comparison to those obtained for human CAs ( $\alpha$-CAs) and other bacterial $\gamma$-CAs using the sulfonamides/sulfamates that are shown in Fig. 1. This study may be of interest for designing new types of inhibitors that may have clinical applications.

In Table 1 , the rate constants and related kinetic values $\left(\mathrm{k}_{c a t}, \mathrm{~K}_{M}\right.$ and $\mathrm{k}_{\text {cat }} / \mathrm{K}_{M}$ ) for the $\gamma$-CA identified in the genome of B. pseudomallei, and the inhibition constant values $\left(\mathrm{K}_{I}\right)$ for the inhibitor acetazolamide (5-acetamido-1,3,4-thiadiazole-2-sulfonamide) and BpsCA $\gamma$ are shown. These data were compared to the kinetic parameters of other CAs belonging to $\alpha$-, $\beta$ - and $\gamma$-classes identified in different organisms. The catalytic activity of these enzymes was determined using the 'stopped-flow' technique. ${ }^{47}$ The kinetic parameters for BpsCA $\gamma$ were: $\mathrm{k}_{\text {cat }}$ of $5.3 \times 10^{5} \mathrm{~s}^{-1}$ and $\mathrm{k}_{\text {cat }} / \mathrm{K}_{\mathrm{m}}$ of
$2.5 \times 10^{7} \mathrm{M}^{-1} \times \mathrm{s}^{-1}$ (Table 1 ). BpsCA $\gamma$ possesses a moderate $\mathrm{CO}_{2}$ hydrase activity when compared with the human isoform hCA I, which is similar to the bacterial $\gamma$-CAs from various pathogenic bacteria (Porphyromonas gingivalis, an oral cavity pathogenic bacterium; Vibrio cholerae, etiological agent of cholera; Table 1). ${ }^{10,13,30,34,42,48-50}$ Furthermore, the BpsCA $\gamma$ activity was effectively inhibited ( $\mathrm{K}_{\mathrm{I}}$ of $\left.149 \mathrm{nM}\right)$ by the clinically used sulfonamide inhibitor acetazolamide.

To determine the hydratase activity of the BpsCA $\gamma$, this enzyme was analyzed using protonographic analysis, ${ }^{51-53}$ which is a new technique in which $\mathrm{pH}$ changes resulting from CAs on SDS-PAGE can be determined colorimetrically. In Fig. 2, protonograms obtained using the commercially available bovine bCA ( $\alpha-C A)$ and the recombinant BpsCA $\gamma$ are shown.

The protonogram of bCA showed a single band of activity corresponding to a monomer of $30 \mathrm{kDa}$ corresponding to the mass of the monomer bCA and consistent with mammalian $\alpha$-CAs being active as monomers (Fig. 2). ${ }^{21,22,44,54-56}$ The protonographic analysis of BpsCA $\gamma$ showed a band of activity at the molecular weight of $22 \mathrm{kDa}$. It has been reported that $\gamma$-CAs catalyze the hydration of carbon dioxide to bicarbonate and protons when the $\gamma$-CAs monomers assemble into a trimer to form a triangular motif with a real molecular weight of about $65 \mathrm{kDa} .{ }^{57,58}$ The apparent molecular weight of $22 \mathrm{kDa}$ on the SDS-PAGE/protonogram is due to the SDS concentration, which results from the separation of the trimeric state of the protein allowing the migration of the enzyme 
Table 1

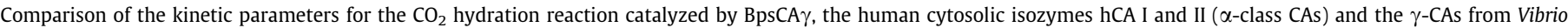

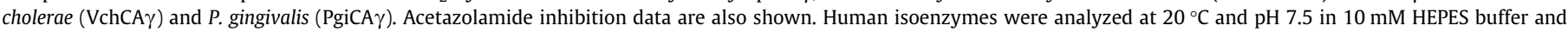
$20 \mathrm{mM} \mathrm{Na}_{2} \mathrm{SO}_{4}$, while the bacterial enzymes were measured at $20^{\circ} \mathrm{C}, \mathrm{pH} 8.3$ in $20 \mathrm{mM}$ TRIS buffer and $20 \mathrm{mM} \mathrm{NaClO}_{4}$.

\begin{tabular}{|c|c|c|c|c|c|}
\hline Enzyme & Activity level & Class & $\mathrm{k}_{\text {cat }}\left(\mathrm{s}^{-1}\right)$ & $\mathrm{k}_{\text {cat }} / \mathrm{K}_{\mathrm{m}}\left(\mathrm{M}^{-1} \mathrm{~s}^{-1}\right)$ & $\mathrm{K}_{\mathrm{I}}$ (acetazolamide) (nM) \\
\hline hCA I & Moderate & $\alpha$ & $2.0 \times 10^{5}$ & $5.0 \times 10^{7}$ & 250 \\
\hline hCA II & Very high & $\alpha$ & $1.4 \times 10^{6}$ & $1.5 \times 10^{8}$ & 12 \\
\hline VchCA $\gamma$ & Moderate & $\gamma$ & $7.39 \times 10^{5}$ & $6.4 \times 10^{7}$ & 473 \\
\hline PgiCA $\gamma$ & Moderate & $\gamma$ & $4.1 \times 10^{5}$ & $5.4 \times 10^{7}$ & 324 \\
\hline $\mathrm{BpsCA} \gamma$ & Moderate & $\gamma$ & $5.3 \times 10^{5}$ & $2.5 \times 10^{7}$ & 149 \\
\hline
\end{tabular}

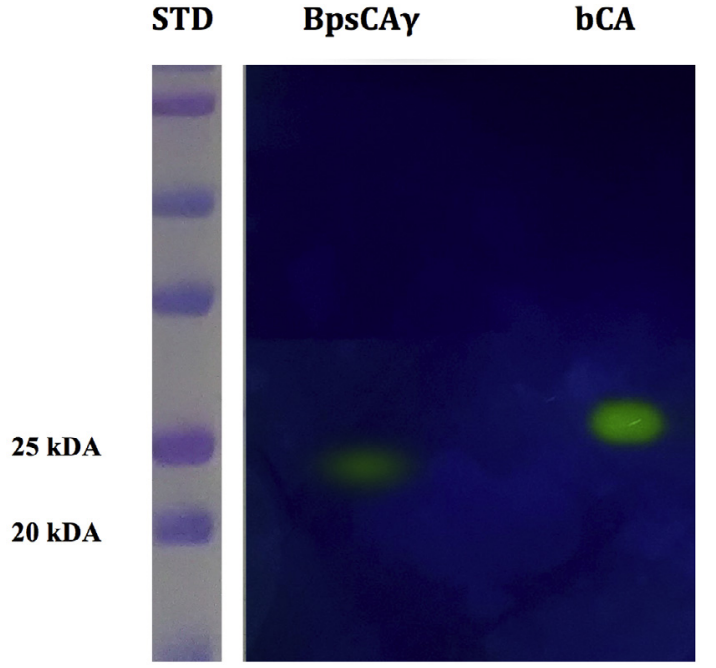

Fig. 2. Protonographic analysis of BpsCA $\gamma$. The gel was loaded with bCA and BpsCA $\gamma$. STD corresponds to standards and the yellow band denotes CA activity due to the change of color of the $\mathrm{pH}$ indicator.

as a monomer (see Fig. 2). The yellow band found in correspondence of the inactive monomeric form of BpsCA $\gamma$ is expected because at the end of the electrophoretic run, the SDS is removed from the gel. This procedure led to the rearrangement of $\gamma$-CA monomers in the gel and the final result is the reconstitution of the active trimeric form of the $\gamma$-CA. ${ }^{52,53}$

Here, we report the sulfonamide/sulfamate inhibition study of BpsCA $\gamma$ comparing it with data obtained for the human cytosolic isozymes hCA I and II ( $\alpha$-class CAs) and the $\gamma$-CAs from Vibrio cholerae (VchCA $\gamma$ ). The following structure-activity relationship (SAR) may be concluded by considering the inhibition data in Table 2:

(i) BpsCA $\gamma$ is less sensitive to sulfonamide CAIs compared to other $\alpha$ - (e.g., hCA II) or $\gamma$-CAs (e.g., VchCA $\gamma$ ) investigated earlier, ${ }^{8}$ for which many nanomolar (and low nanomolar) inhibitors were found (Table 2). It may be observed that only three sulfonamides had $\mathrm{K}_{\mathrm{I}} \mathrm{S}$ in the range of $149-653 \mathrm{nM}$, all the other ones having inhibition constants $>1 \mu \mathrm{M}$. The most effective BpsCA $\gamma$ inhibitors were acetazolamide $\mathbf{A A Z}$, benzolamide BZA, and metanilamide $\mathbf{1}$. They incorporate both aromatic (1) and heterocyclic (AAZ, BZA) sulfonamide motifs. However, as discussed below, small changes in their scaffolds can result in a dramatic decrease in inhibitory activity.

(ii) Moderate to low BpsCA $\gamma$ inhibitory activity was observed for the following derivatives: 2, 3, 14, 15, 17-23, MZA, EZA, TPM, SLP, IND, SLT and SAC, which had $K_{\mathrm{I}} \mathrm{S}$ in the range of $1270-9560 \mathrm{nM}$ (Table 2). Apart from the clinically used derivatives, which incorporate heterocyclic rings (MZA, EZA), aromatic (SLP, IND, SLT) and sugar (TPM) scaffolds, the secondary, acyl-sulfonamide SAC was also among this
Table 2

Sulfonamides/sulfamates inhibition constants $\left(K_{\mathrm{I}} \mathrm{s}, \mathrm{nM}\right)$ for the human $\alpha$-CAs (isoforms hCA I and II) and the $\gamma$-CAs identified in the genome of $V$. cholera and $B$. pseudomallei.

\begin{tabular}{|c|c|c|c|c|}
\hline \multicolumn{5}{|l|}{$\mathrm{K}_{\mathrm{I}} \mathrm{s}, \mathrm{nM}^{*}$} \\
\hline Inhibitor & hCA I & hCA II & VchCA $\gamma$ & BpsCA $\gamma$ \\
\hline 1 & 45,400 & 295 & 672 & 574 \\
\hline 2 & 25,000 & 240 & 95.3 & 1720 \\
\hline 3 & 28,000 & 300 & 93.6 & 1550 \\
\hline 4 & 78,500 & 320 & 76.3 & $>50,000$ \\
\hline 5 & 25,000 & 170 & 80.6 & $>50,000$ \\
\hline 6 & 21,000 & 160 & 69.0 & $>50,000$ \\
\hline 7 & 8300 & 60 & 73.6 & $>50,000$ \\
\hline 8 & 9800 & 110 & 73.6 & 12,500 \\
\hline 9 & 6500 & 40 & 95.3 & $>50,000$ \\
\hline 10 & 6000 & 70 & 544 & $>50,000$ \\
\hline 11 & 5800 & 63 & 87.1 & 14,000 \\
\hline 12 & 8400 & 75 & 563 & 23,500 \\
\hline 13 & 8600 & 60 & 66.2 & 18,400 \\
\hline 14 & 9300 & 19 & 69.9 & 1810 \\
\hline 15 & 6 & 2 & 88.5 & 9650 \\
\hline 16 & 164 & 46 & 556 & 10,800 \\
\hline 17 & 185 & 50 & 6223 & 1825 \\
\hline 18 & 109 & 33 & 5100 & 1500 \\
\hline 19 & 95 & 30 & 4153 & 1838 \\
\hline 20 & 690 & 12 & 5570 & 1810 \\
\hline 21 & 55 & 80 & 764 & 1335 \\
\hline 22 & 21,000 & 125 & 902 & 1805 \\
\hline 23 & 23,000 & 133 & 273 & 1700 \\
\hline 24 & 24,000 & 125 & 73.3 & 24,500 \\
\hline AAZ & 250 & 12 & 473 & 149 \\
\hline MZA & 50 & 14 & 494 & 1595 \\
\hline EZA & 25 & 8 & 85.1 & 1865 \\
\hline DCP & 1200 & 38 & 1230 & $>50,000$ \\
\hline DZA & 50,000 & 9 & 87.3 & 2260 \\
\hline BRZ & 45,000 & 3 & 93.0 & 1270 \\
\hline BZA & 15 & 9 & 77.6 & 653 \\
\hline TPM & 250 & 10 & 68.8 & 3010 \\
\hline ZNS & 56 & 35 & 725 & $>50,000$ \\
\hline SLP & 1200 & 40 & 77.9 & 5600 \\
\hline IND & 31 & 15 & 91.3 & 1800 \\
\hline VLX & $>50,000$ & 43 & 817 & $>50,000$ \\
\hline CLX & 50,000 & 21 & 834 & $>50,000$ \\
\hline SLT & 374 & 9 & 464 & 8900 \\
\hline SAC & 18,540 & 5959 & 550 & 1550 \\
\hline HCT & 328 & 290 & 500 & $>50,000$ \\
\hline
\end{tabular}

* Mean from 3 different assays. Errors in the range of $\pm 10 \%$ of the reported values (data not shown).

type of CAIs. Other derivatives in this category are either simple aromatic compounds (sulfanilamide 2, benzene-1,3disulfonamide 3, 4-hydroxybenzenesulfonamide $\mathbf{1 5}$, its hydroxyethyl congener 17, 4-carboxybenzenesulfonamide 18) or incorporate more elaborated scaffolds (as in 19-23) that are prevalent for the sulfonylated sulfonamide type (e.g., aminobenzolamide $\mathbf{2 0}$ and benzolamide BZA are typical examples of such a scaffold). However, relatively minor changes in the scaffold results in a dramatic change in the CA inhibitory activity. For example, the isomers $\mathbf{1}$ and $\mathbf{2}$ that differ in the position of the amino group with respect to the 
sulfonamide, differ in a factor of 3 in their BpsCA $\gamma$ inhibitory activity. In the structurally related series 15-17, the compound incorporating the longer spacer $(n=2,17)$ inhibited BpsCA $\gamma$ more effectively by over a factor of 5 than the compound 15 that had a shorter spacer $(n=0)$. However, the derivative with the hydroxymethyl moiety $\mathbf{1 6}$ was a much weaker inhibitor, with a $\mathrm{K}_{\mathrm{I}}$ of $10.8 \mu \mathrm{M}$. Other such examples are abundant in this series of compounds that was investigated, with the deprotected acetazolamide 13 being less effective as an inhibitor than AAZ by over a factor of 100 . In contrast, for methazolamide and the deacetylated methazolamide (14) pair, the difference of activity is minor, with 14 being only 1.13 times weaker as an inhibitor compared to MZA (Table 2). All these data are indicative of the fact that the recognition between the enzyme active site and the inhibitor molecules is governed by multiple factors that are challenging to elucidate without an X-ray crystal structure of the enzyme or high-resolution hydrogen deuterium exchange data. In fact, up until now, a very limited number of $\gamma$-CAs have been crystallized, and no crystal structures have been reported for a $\gamma$-CA and inhibitor complex. . $^{57-60}$

(iii) The inhibitory action against $\operatorname{BpsCA} \gamma$ was very low for the following compounds: 8, 11-13, 16 and 24, which had $\mathrm{K}_{\mathrm{I}} \mathrm{S}$ in the range of $10,800-24,500 \mathrm{nM}$. Again, they belong to heterogeneous classes of sulfonamides, with aromatic monosulfonamides $(\mathbf{8}, \mathbf{1 6}, \mathbf{2 4})$, disulfonamides $(\mathbf{1 1}, \mathbf{1 2})$, and a heterocylic sulfonamide derivative, deacetylated acetazolamide 13 (Table 1 ).

(iv) A number of the investigated sulfonamides did not inhibit BpsCA $\gamma$ up to $50 \mu \mathrm{M}$, which is the maximum concentration of inhibitor in the assay system. They are: 4-7, 9, 10, DCP, ZNS, VLX, CLX and HCT. Whereas some of these compounds have rather bulky, complicated scaffold (VLX, CLX and HCT), which could be sterically hindered from binding within the rather shallow $\gamma$-CA active site, the simple derivatives 4-7, $\mathbf{9}$ and $\mathbf{1 0}$ should not experience such issues with binding. It is thus obvious that SAR for the inhibition of this enzyme is rather complex and poorly understood with the available data at this moment.

(v) The inhibition profile of BpsCA $\gamma$ is very different from that of other $\alpha$ - or $\gamma$-CAs of mammalian or bacterial origin, making this enzyme a peculiar case, which deserves further investigation.

In conclusion, we have cloned and characterized the kinetic profile of a new $\gamma$-CA in the genome of the bacterial pathogen Burkholderia pseudomallei, the etiological agent of melioidosis, an endemic disease of tropical and sub-tropical regions of the world. For the physiologic $\mathrm{CO}_{2}$ hydration reaction, this new enzyme, BpsCA $\gamma$, exhibits significant catalytic activity $\left(\mathrm{k}_{\text {cat }}\right.$ of $5.3 \times 10^{5} \mathrm{~s}^{-1}$ and $\mathrm{k}_{\mathrm{cat}} / \mathrm{K}_{\mathrm{m}}$ of $2.5 \times 10^{7} \mathrm{M}^{-1} \times \mathrm{s}^{-1}$ ). Few sulfonamides were effective BpsCA $\gamma$ inhibitors, with acetazolamide, benzolamide and metanilamide being the most effective inhibitors identified $\left(K_{\mathrm{I}} \mathrm{S}\right.$ of $\left.149-653 \mathrm{nM}\right)$ whereas other sulfonamides/sulfamates such as ethoxzolamide, topiramate, sulpiride, indisulam, sulthiame and saccharin were less effective $\left(\mathrm{K}_{\mathrm{I}} \mathrm{S}\right.$ of 1.27-9.56 $\mu \mathrm{M})$. As Burkholderia pseudomallei is resistant to many classical antibiotics, discovering compounds that interfere with crucial enzymes in its life cycle may lead to the development of antibiotics with novel mechanisms of action.

\section{Acknowledgment}

This work was supported in part by the Distinguished Scientists Fellowship Program (DSFP) from King Saud University, Saudi Arabia.

\section{References}

1. Vullo D, De Luca V, Del Prete S, et al. Bioorg Med Chem. 2015;23:1728.

2. (a) Supuran CT. Biochem J. 2016;473:2023;

(b) Vullo D, Kupriyanova EV, Scozzafava A, Capasso C, Supuran CT. Bioorg Med Chem. 2014;22:1667.

3. (a) Supuran CT. Nat Rev Drug Discov. 2008;7:168;

(b) Monti SM, De Simone G, Dathan NA, et al. Bioorg Med Chem Lett. 2013;23:1626.

4. Migliardini F, De Luca V, Carginale V, et al. J Enzyme Inhib Med Chem. 2014;29:146.

5. Vullo D, Del Prete S, Capasso C, Supuran CT. Bioorg Med Chem Lett. 2016;26:1381.

6. (a) Supuran CT, Capasso C. J Enzyme Inhib Med Chem. 2016;31:1254;

(b) Supuran CT. Expert Opin Drug Discov. 2016. http://dx.doi.org/10.1080/ 17460441.2017.1253677 (in press).

7. Del Prete S, Vullo D, De Luca V, et al. Bioorg Med Chem Lett. 2016;26:4184.

8. Del Prete S, De Luca V, Vullo D, et al. J Enzyme Inhib Med Chem. 2016;31:1156.

9. Capasso C, Supuran CT. Curr Top Med Chem. 2016;16:2359.

10. Vullo D, Del Prete S, De Luca V, et al. Bioorg Med Chem Lett. 2016;26:1406.

11. Supuran CT, Capasso C. Expert Opin Ther Targets. 2015;19:551.

12. Ferraroni M, Del Prete S, Vullo D, Capasso C, Supuran CT. Acta Crystallogr D Biol Crystallogr. 2015;71:2449.

13. (a) Supuran CT. J Enzyme Inhib Med Chem. 2013;28:229;

(b) Del Prete S, Vullo D, De Luca V, et al. J Enzyme Inhib Med Chem. 2015;30:366.

14. (a) De Simone G, Monti SM, Alterio V, et al. Bioorg Med Chem Lett. 2015;25:2002;

(b) De Simone G, Supuran CT. Biochim Biophys Acta. 2010;1804:404.

15. De Luca V, Del Prete S, Carginale V, Vullo D, Supuran CT, Capasso C. J Enzyme Inhib Med Chem. 2015;30:989. The identification of the gene encoding for $B$. pseudomallei $\gamma$-CA (Bps $\gamma \mathrm{CA}$ ) was performed at the link http://www.ncbi.nlm. nih.gov/genome/selecting the genome of "B. pseudomallei". The $\gamma$-CA gene of $B$. pseudomallei (accession number: WP_038762492.1) was identified running the "BLAST" program and using the nucleotide sequences of bacterial $\gamma$-CAs as query sequence. The GeneArt Company (Invitrogen), specialized in gene synthesis, designed the synthetic Bps $\gamma$ CA gene (Bps $\gamma$ CA-DNA) encoding for the Bps $\gamma C A$ ( $\beta$-CA of 358 amino acid residues) containing four base-pair sequences (CACC) necessary for directional cloning at the $5^{\prime}$-end of the PfCAdom gene. The recovered PfCAdom gene and the linearized expression vector ( $\mathrm{pET}-100 / \mathrm{D}-\mathrm{TOPO}$ ) were ligated by T4 DNA ligase to form the expression vector pET-100/Bps $\gamma$ CA. Arctic Express DE3 competent cells (Agilent) were transformed with pET-100/Bps $\gamma \mathrm{CA}$, grown at $20^{\circ} \mathrm{C}$ and induced with $1 \mathrm{mM}$ IPTG. After $30 \mathrm{~min}$ was added $\mathrm{ZnSO}_{4}(0.5 \mathrm{mM})$ to the culture medium and cells were grown for additional $6 \mathrm{~h}$. Subsequently, cells were harvested and resuspended in the following buffer: $50 \mathrm{mM}$ Tris/ $\mathrm{HCl}, \mathrm{pH} 8.0,0.5 \mathrm{mM}$ PMSF, and $1 \mathrm{mM}$ benzamidine. Cells were then disrupted by sonication at $4{ }^{\circ} \mathrm{C}$. After centrifugation at $12,000 \times \mathrm{g}$ for $45 \mathrm{~min}$, the supernatant was incubated with His Select HF nickel affinity gel resin (Sigma) equilibrated in lysis buffer for $30 \mathrm{~min}$. Following centrifugation at $2000 \times \mathrm{g}$, the resin was washed in wash buffer ( $50 \mathrm{mM}$ Tris/ $\mathrm{HCl}, \mathrm{pH} 8.0,500 \mathrm{mM} \mathrm{KCl}, 20 \mathrm{mM}$ imidazole). The protein was eluted with the wash buffer containing $200 \mathrm{mM}$ imidazole. Collected fractions were dialyzed against $50 \mathrm{mM}$ Tris/ $\mathrm{HCl}, \mathrm{pH}$ 8.0. At this stage of purification the protein was at least $85 \%$ pure and the obtained recovery was of $0.1 \mathrm{mg}$ of the recombinant protein..

16. Capasso C, Supuran CT. J Enzyme Inhib Med Chem. 2015;30:325.

17. (a) Capasso C, Supuran CT. Expert Opin Ther Targets. 2015;19:1689;

(b) Bayram E, Senturk M, Kufrevioglu OI, Supuran CT. Bioorg Med Chem. 2008;16:9101.

18. Kikutani S, Nakajima K, Nagasato C, Tsuji Y, Miyatake A, Matsuda Y. Proc Natl Acad Sci USA. 2016;113:9828.

19. (a) Dedeoglu N, De Luca V, Isik S, et al. Bioorg Med Chem. 2015;23:2995; (b) Supuran CT, Clare BW. Eur J Med Chem. 1999;34:41.

20. De Simone G, Di Fiore A, Capasso C, Supuran CT. Bioorg Med Chem Lett. 2015;25:1385.

21. Capasso C, Supuran CT. Curr Med Chem. 2015;22:2130.

22. Ozensoy Guler O, Capasso C, Supuran CT. J Enzyme Inhib Med Chem. 2016;31:689.

23. Capasso C, Supuran CT. J Enzyme Inhib Med Chem. 2014;29:379.

24. (a) Supuran CT. J Enzyme Inhib Med Chem. 2012;27:759; (b) Supuran CT. Curr Pharm Des. 2008;14:603.

25. Vullo D, Del Prete S, Fisher GM, et al. Bioorg Med Chem. 2015;23:526.

26. Vullo D, De Luca V, Del Prete S, et al. Bioorg Med Chem Lett. 2015;25:3550.

27. (a) Dedeoglu N, DeLuca V, Isik S, et al. Bioorg Med Chem Lett. 2015;25:2291; (b) Menchise V, De Simone G, Alterio V, et al. J Med Chem. 2005;48:5721.

28. (a) Vullo D, Del Prete S, Osman SM, et al. Bioorg Med Chem Lett. 2014;24:275; (b) Scozzafava A, Menabuoni L, Mincione F, Briganti F, Mincione G, Supuran CT. I Med Chem. 2000;43:4542.

29. Vullo D, Del Prete S, Osman SM, et al. Bioorg Med Chem Lett. 2014;24:240.

30. Prete SD, Vullo D, Osman SM, et al. Bioorg Med Chem. 2014;22:4537.

31. (a) Nishimori I, Vullo D, Minakuchi T, Scozzafava A, Capasso C, Supuran CT Bioorg Med Chem. 2014;22:2939;

(b) Innocenti A, Öztürk Sarıkaya SB, Gülçin I, Supuran CT. Bioorg Med Chem. 2010;18:2159. 
32. (a) Ceruso M, Del Prete S, Alothman Z, Capasso C, Supuran CT. ACS Med Chem Lett. 2014;5:826;

(b) Borras J, Scozzafava A, Menabuoni L, et al. Bioorg Med Chem. 1999;7:2397.

33. (a) De Simone G, Supuran CT. J Inorg Biochem. 2012;111:117;

(b) Scozzafava A, Briganti F, Mincione G, Menabuoni L, Mincione F, Supuran CT. J Med Chem. 1999;42:3690.

34. Del Prete S, Vullo D, De Luca V, et al. Bioorg Med Chem. 2016;24:3413.

35. (a) Vullo D, Sai Kumar RS, Scozzafava A, Capasso C, Ferry JG, Supuran CT. Bioorg Med Chem Lett. 2013;23:6706;

(b) Supuran CT, Ilies MA, Scozzafava A. Eur J Med Chem. 1998;33:739.

36. Modak JK, Liu YC, Machuca MA, Supuran CT, Roujeinikova A. PLoS One. 2015; 10 : e0127149.

37. Syrjanen L, Kuuslahti M, Tolvanen M, Vullo D, Parkkila S, Supuran CT. Bioorg Med Chem. 2015;23:2303.

38. (a) Vullo D, Voipio J, Innocenti A, et al. Bioorg Med Chem Lett. 2005;15:971; (b) Vullo D, Isik S, Bozdag M, Carta F, Supuran CT. J Enzyme Inhib Med Chem. 2015;30:773.

39. D'Ambrosio K, Carradori S, Monti SM, et al. Chem Commun (Camb) 2015;51:302.

40. Korkmaz N, Obaidi OA, Senturk M, Astley D, Ekinci D, Supuran CT. J Enzyme Inhib Med Chem. 2015;30:75.

41. Vullo D, De Luca V, Del Prete S, et al. Bioorg Med Chem Lett. 2016;26:1253.

42. Del Prete S, Vullo D, De Luca V, et al. Bioorg Med Chem. 2016:24:1115.

43. De Luca V, Vullo D, Del Prete S, et al. Bioorg Med Chem. 2016;24:835.

44. (a) Annunziato G, Angeli A, D’Alba F, et al. ChemMedChem. 2016;11:1904; (b) Scozzafava A, Menabuoni L, Mincione F, Supuran CT. J Med Chem. 2002;45:1466.

45. (a) Stephens DP, Thomas JH, Ward LM, Currie BJ. Crit Care Med. 2016;44:1500; (b) Supuran CT, Scozzafava A, Mastrolorenzo A. Expert Opin Ther Pat 2001;11:221.

46. Gilad J, Schwartz D, Amsalem Y. Int J Biomed Sci. 2007;3:144.

47. Khalifah RG. J Biol Chem. 1971;246:2561. An applied photophysics stopped flow instrument has been used for assaying the $\mathrm{CA}$ catalyzed $\mathrm{CO}_{2}$ hydration activity. Phenol red (at a concentration of $0.2 \mathrm{mM}$ ) has been used as indicator, working at the absorbance maximum of $557 \mathrm{~nm}$, with $20 \mathrm{mM}$ TRIS (pH 8.3) as buffer, and $20 \mathrm{mM} \mathrm{NaClO}_{4}$ (for maintaining constant the ionic strength), following the initial rates of the CA-catalyzed $\mathrm{CO}_{2}$ hydration reaction for a period of $10-100 \mathrm{~s}$. The $\mathrm{CO}_{2}$ concentrations ranged from 1.7 to $17 \mathrm{mM}$ for the determination of the kinetic parameters (by Lineweaver-Burk plots) and inhibition constants. For each inhibitor at least six traces of the initial $5-10 \%$ of the reaction have been used for determining the initial velocity. The uncatalyzed rates were determined in the same manner and subtracted from the total observed rates. Stock solutions of inhibitor $(10-100 \mathrm{mM})$ were prepared in distilleddeionized water and dilutions up to $0.01 \mathrm{mM}$ were done thereafter with the assay buffer. Inhibitor and enzyme solutions were preincubated together for $15 \mathrm{~min}$ at room temperature prior to assay, in order to allow for the formation of the E-I complex or for the eventual active site mediated hydrolysis of the inhibitor. The inhibition constants were obtained by non-linear least-squares methods using PRISM 3 and the Cheng-Prusoff equation, as reported earlier, and represent the mean from at least three different determinations. All CA isoforms were recombinant ones obtained in-house. All salts/small molecules were of the highest purity available, from Sigma-Aldrich (Milan, Italy)..

48. Del Prete S, Isik S, Vullo D, et al. J Med Chem. 2012;55:10742.

49. Alafeefy AM, Ceruso M, Al-Tamimi AM, Del Prete S, Supuran CT, Capasso C. J Enzyme Inhib Med Chem. 2015;30:592.

50. Del Prete S, Vullo D, De Luca V, et al. Bioorg Med Chem Lett. 2013;23:4067.

51. Del Prete S, De Luca V, Supuran CT, Capasso C. J Enzyme Inhib Med Chem. 2015;30:920.

52. Del Prete S, De Luca V, Iandolo E, Supuran CT, Capasso C. Bioorg Med Chem. $2015 ; 23: 3747$.

53. De Luca V, Del Prete S, Supuran CT, Capasso C. J Enzyme Inhib Med Chem. 2015;30:277.

54. (a) Supuran CT. J Enzyme Inhib Med Chem. 2016;31:345;

(b) Winum JY, Scozzafava A, Montero JL, Supuran CT. Med Res Rev. 2006;26:767.

55. Supuran CT. Expert Opin Ther Pat. 2013;23:677.

56. Neri D, Supuran CT. Nat Rev Drug Discov. 2011;10:767.

57. Zimmerman SA, Ferry JG. Curr Pharm Des. 2008;14:716.

58. Zimmerman SA, Ferry JG, Supuran CT. Curr Top Med Chem. 2007;7:901.

59. Kumar RS, Ferry JG. Subcell Biochem. 2014;75:77.

60. Tripp BC, Smith K, Ferry JG. J Biol Chem. 2001;276:48615. 